\title{
Absorption kinetics of dietary hydrolysis products in conscious pigs given diets with different amounts of fish protein
}

\author{
1. Amino-nitrogen and glucose
}

\author{
BY A. RÉRAT, P. VAISSADE AND P. VAUGELADE \\ Laboratoire de Physiologie de la Nutrition, INRA, Centre de Recherches de Jouy-en-Josas, \\ 78350 Jouy-en-Josas, France
}

(Received 20 January 1987 - Accepted 16 February 1988)

1. Concentrations of amino-nitrogen, glucose, reducing sugars and lactic acid in blood obtained from arterial and portal permanent catheters were measured together with the portal hepatic blood flow-rate during a postprandial period of $8 \mathrm{~h}$ in twenty unanaesthetized pigs (initial mean body-weight 52.3 (SEM 0.9 ) $\mathrm{kg}$ ) receiving experimental meals $(200-1000 \mathrm{~g})$ at $3-4 \mathrm{~d}$ intervals from 6-8 to $20 \mathrm{~d}$ after surgical implantation of the catheters and electromagnetic flow probe. The semi-synthetic starch-based diets contained variable amounts of fish meal giving crude protein (nitrogen $\times 6.25 ; \mathrm{CP}$ ) concentrations $(\mathrm{g} \mathrm{CP} / \mathrm{kg}$ ) of 80 (seven meals), 120 (twenty-two meals), 160 (six meals) and 240 (nine meals).

2. After the meal the concentration of amino- $\mathrm{N}$ increased with increasing levels of protein intake and increased more in the portal than in the arterial blood. There were significant relations between amounts of amino- $\mathrm{N}$ appearing in the portal blood at various time-intervals after the meal and the level of protein intake. Values for the ratio, amount absorbed within $8 \mathrm{~h}$ : amount ingested (absorption coefficient: 0.633 for a mean intake of $13.4 \mathrm{~g} \mathrm{~N}$ ) decreased with increasing level of protein intake.

3. There was a rise in glycaemia after the meal, increasing with the amount of carbohydrate eaten, and this was more marked in the portal than in the arterial blood. There were also significant relations between amounts of glucose absorbed and amounts of starch ingested. However, the appearance of glucose in the portal blood was less marked than that of amino- $\mathrm{N}$ since the absorption coefficient within $8 \mathrm{~h}$ was lower $(0.504$ for a mean intake of $291 \mathrm{~g}$ reducing sugars). This was most probably due to a larger uptake of glucose by the intestinal cell wall.

4. Amounts of lactic acid appearing in the portal vein during the post-prandial period did not depend on amounts ingested; they ranged from 3 to $1.6 \mathrm{~g} / \mathrm{h}$ from the 1 st to the 8 th hour after the meal.

The apparent digestibility of dietary nitrogen measured by the difference between amounts ingested and amounts excreted in the faeces is highly variable according to diet composition, especially the type of protein used (Agricultural Research Council, 1967). However, only the disappearance from the gut and not necessarily the appearance of nutrients in the body can be quantified in that way. The situation is complicated by the fact that nutrients could have been destroyed or changed either by the digestive microflora or by the enterocyte during absorption. Furthermore, only the overall disappearance of nutrients can be measured with this method and not the kinetics which determine their appearance at the sites of protein synthesis. This synthesis requires a simultaneous supply of amino acids and sugars (Munro, 1949).

Analysis of the relation between apparent digestibility and metabolic utilization of nutrients should be based in part on the study of the kinetics of appearance of nutrients in the efferent blood of the digestive tract (portal blood). We have therefore developed a method based on the enrichment of the portal blood following meal intake, as evidenced by the porto-arterial difference in the nutrient concentration, quantified by a simultaneous determination of the portal blood flow-rate (Rérat et al. 1980). This method was used to study the absorption kinetics of amino- $\mathrm{N}$, amino acids, reducing sugars and glucose and to determine the amount and type of nutrients absorbed after ingestion of fish-meal diets by conscious pigs.

The general aspects of the appearance of amino- $\mathrm{N}$ and glucose in the portal vein will be 
Table 1. Composition of the diet used before and between experimental meals and the protein-free diet $(\mathrm{g} / \mathrm{kg})$

\begin{tabular}{lcc}
\hline \hline Ingredients & Protein-free diet & $\begin{array}{c}\text { Diet used before } \\
\text { experimental meals* }\end{array}$ \\
\hline Fish meal $\dagger$ & - & 170 \\
Peanut oil & 50 & 41 \\
Granulated sugar & 50 & 41 \\
Purified cellulose $\ddagger$ & 120 & 100 \\
Maize starch & 640 & 532 \\
Minerals§ & 30 & 25 \\
Vitamins§ & 10 & 8 \\
Vermiculite $\|$ & 100 & 83 \\
\hline
\end{tabular}

* Dry matter $890 \mathrm{~g} / \mathrm{kg}$ fresh matter (FM).

$\dagger$ Composition: crude protein (nitrogen $\times 6.25$ ) $706 \mathrm{~g} / \mathrm{kg} \mathrm{FM}$, dry matter $927.5 \mathrm{~g} / \mathrm{kg} \mathrm{FM}$, amino acids (AA; $\mathrm{g} / \mathrm{kg} \mathrm{FM}$ ): lysine 52 , histidine 15 , phenylalanine 28 , leucine 55 , isoleucine 33 , methionine 20 , valine 39 , threonine 30 , serine 27 , arginine 39 , aspartic acid + asparagine 67 , proline 31 , glutamic acid +glutamine 100 , glycine 44 , alanine 46 , cystine 5, tyrosine 17 , total AA $649, \mathrm{~N} 139 \mathrm{~g} / \mathrm{kg}$ total AA (from R. Calmes, unpublished results).

$\ddagger$ Purified wood cellulose.

$\S$ Mineral and vitamin supplements described by Henry \& Rérat (1964).

Mica powder.

treated in the first paper and results concerning the different amino acids individually will be reported in a second paper (Rérat et al. 1988).

\section{EXPERIMENTAL \\ Animals}

Twenty castrated Large White male pigs of initial mean body-weight 52.3 (SEM 0.9) kg were used. For a period of about 1 month before the trial, they received a pre-experimental diet $(800-1000 \mathrm{~g} / \mathrm{meal})$ twice daily at 09.00 and 17.00 hours, the composition of which is given in Table 1. The mean growth rate of the animals during this period was $600 \mathrm{~g} / \mathrm{d}$. Each animal was then fitted with an electromagnetic flow probe for measuring the blood flowrate in the portal vein, and with two catheters, one placed in the portal vein and the other in the left brachiocephalic artery through the carotid route by procedures described elsewhere (Rérat, 1971; Rérat et al. 1980). The animals began to eat 1-2 d after the operation and rapidly recovered their normal growth rate. They were given penicillin $\left(1.2 \times 10^{6} \mathrm{IU} / \mathrm{d}\right)$ and streptomycin $(1 \mathrm{~g} / \mathrm{d})$ for 3-5 d after surgery.

\section{Diets and feeding conditions}

Before the operation and until the end of the experiments, the animals were placed in restraining cages. The experiments began 6-10 d after the cannulas had been placed in position and when the animals had recovered a normal appetite and growth rate. After a fasting period of $18 \mathrm{~h}$ to avoid the effect of the previous meal (Rérat et al. 1980), the animals received in one daily meal (09.00 hours) a given amount (200-1000 g) of one of the experimental diets composed of a protein-free feed (Table 1) mixed with different amounts of fish meal so as to obtain different crude protein $(\mathrm{N} \times 6.25 ; \mathrm{CP})$ concentrations. In the initial experimental design, it was planned that each animal should receive six experimental meals with various protein levels at the rate of three per week during 2 weeks, each postprandial experimental period of blood samplings $(8 \mathrm{~h})$ being followed by a period of recovery during which the animal should receive the well-balanced pre-experimental diet 
(Table 1). However, because of experimental difficulties (early obstruction of catheters, early dysfunction of flow probes) and the fact that only meals consumed in less than $20 \mathrm{~min}$ were taken into account, the number of actual experimental meals per animal varied between one and six, the same animal receiving one experimental diet only once at a given level of intake. Thus, forty-four meals were eaten by animals under satisfactory conditions, i.e. seven, twenty-two, six and nine meals containing $80,120,160$ and $240 \mathrm{~g} \mathrm{CP} / \mathrm{kg}$ respectively. The diet containing $120 \mathrm{~g} \mathrm{CP} / \mathrm{kg}$ was offered in an amount of $500 \mathrm{~g}$ to twelve animals and $750 \mathrm{~g}$ to six other animals. The other twenty-six experimental meals were given at random according to animal capacities and in situ maintenance of catheters and probe, but with variable protein intakes in a given animal, using variations in the level of dietary protein rather than in the total level of feeding. The different levels of CP $(n 44)$ and carbohydrate intake ( $n$ 41) are given in Figs. 5 (p. 98) and 7 (p. 100).

\section{Measurements}

Blood flow-rate in the portal vein was recorded continuously and blood was sampled over the whole experimental period, i.e. from $30 \mathrm{~min}$ before until $8 \mathrm{~h}$ after the meal. The cannulas were connected directly and continuously to an automatic analyser according to a procedure described elsewhere (Aumaitre et al. 1975). Total reducing sugars (Hoffman, 1937), true glucose (glucose oxidase (EC 1 1 1 . 3 .4) technique; Hill \& Kessler, 1961), and amino-N (trinitrobenzene sulphonate (TNBS); Palmer \& Peters, 1965) were determined. However, the amino acid weight obtained with this method was not exact as it was only possible to determine the number of amino radicals corresponding to a standard solution of amino acids by means of TNBS. The solution included 2.50 (SE 0.05 ) $\mu \mathrm{mol} / \mathrm{ml}$ of the following substances dissolved in $0.125 \mathrm{M}$-hydrochloric acid: alanine, arginine, aspartic acid, half cystine, glutamic acid, glycine, histidine, leucine, lysine, methionine, phenylalanine, proline, serine, threonine, ammonium sulphate; this mixture contained $154 \mathrm{~g}$ $\mathrm{N} / \mathrm{kg}$.

\section{Calculations and limits of the method}

The method used (Rérat, 1971) is based on quantitative determination of the increase in the intestinal blood level of nutrients after the meal by measurement of the porto-arterial differences $\left(C_{p}-C_{a}\right)$ of nutrient concentrations in the gut blood at any moment after the meal and by multiplication of these differences by the corresponding flow-rate $(F)$ and by the duration of digestion according to the formulas:

$$
\begin{aligned}
q & =\left(C_{p}-C_{a}\right) F d t, \\
Q & =\sum_{t_{0}}^{t_{1}} q,
\end{aligned}
$$

where $q$ is the quantity absorbed during the short time $d t(5 \mathrm{~min})$ during which the factors could be considered as constant, $C_{p}$ is the portal concentration, $C_{a}$ is the arterial concentration, $F$ is the blood flow-rate in the portal vein and $Q$ is the quantity absorbed during the post-prandial period between times $t_{0}$ and $t_{1}$. This measurement is not of the total amount absorbed, but only the net influx of nutrients into the portal blood because some nutrients coming from the intestinal lumen or from the arterial blood may be metabolized in the gastrointestinal wall. For an ingested nutrient, the recorded values correspond to absorption minus the gut tissue metabolism when $C_{p}-C_{a}$ is positive, or to the gut tissue metabolism minus the absorption when $C_{p}-C_{a}$ is negative. On the other hand, the synthesis of a non-ingested nutrient by the gastrointestinal wall can be measured in this way (Rérat et al. 1980). 
The weight of total amino acids was arbitrarily calculated from the blood level of amino$\mathrm{N}$ using the classical coefficient $6 \cdot 25$ which was also used to calculate the protein content of the diets on the basis of their $\mathrm{N}$ content. Thus, the absorption coefficient at time $t$ corresponds to the ratio, cumulative amount of $\mathrm{N} \times 6.25$ appearing in the portal vein at time $t$ : amount of protein $(\mathrm{N} \times 6 \cdot 25)$ ingested.

\section{Statistical methods}

Statistical analyses (Snedecor \& Cochran, 1967) involved standard error of the mean, comparison of two groups of unequal size by the Student's $t$ test and regression analyses with the correlation coefficient, $r$, and standard deviation of the regression coefficient, $S_{b}$. Because of the imbalance of the actual experimental design, it was not possible to take into account both within-animal and between-animal variation in regression analyses; because of the random distribution of the forty-four meals to the twenty animals, without repetition of the same meal in the same animal, each meal (defined by the CP content and level of intake) was considered as an individual value. For controlling the validity of the equations thus calculated and discarding the within-animal variations, the regressions were compared with regressions using only values from the first meal given to each of the twenty animals.

\section{RESULTS}

\section{Portal blood flow-rate}

The mean portal blood flow-rate was calculated for each meal from continuous recordings made during the whole experimental period. No relation was found between the mean flowrate and the amounts of sugar or protein ingested. Thus, the blood flow-rate seemed to be a characteristic of the animal on the day of recording and a quantitative determination of the absorption therefore requires a corresponding recording of the blood flow-rate. The mean flow-rate calculated for all animals ( $n$ 20) was 1938 (SEM 96) $\mathrm{ml} / \mathrm{min}$, i.e. 37.41 (SEM $1.79) \mathrm{ml} / \mathrm{min}$ per $\mathrm{kg}$ live weight.

\section{Post-prandial variations in concentration of nutrients (amino- $N$, glucose and lactic acid) in portal and arterial blood}

Amino- $N$ concentration. Variations in the amino- $\mathrm{N}$ concentration $(\mathrm{mg} / \mathrm{l})$ are reported in Fig. 1 for the two levels of ingestion for which there were most measurements $(120 \mathrm{~g} \mathrm{CP} /$ $\mathrm{kg}$, ingestion levels of 500 and $750 \mathrm{~g}$, eighteen animals, eighteen meals). In all experiments ( $n$ 18), the blood levels of amino- $\mathrm{N}$ measured after $18 \mathrm{~h}$ of fasting (initial concentrations; IC) were almost the same in the portal (74 (SEM 2) $\mathrm{mg} / \mathrm{l}$ ) and arterial blood (72 (SEM 2) $\mathrm{mg} / \mathrm{l}$ ). After intake of a meal the amino- $\mathrm{N}$ concentrations rapidly reached maximum values which were higher in the portal than in the arterial blood (110 (SEM 4) mg/lv. 92 (SEM 5) $\mathrm{mg} / 1$ for a $500 \mathrm{~g}$ dietary intake, $P<0.01 ; 117$ (SEM 7) $\mathrm{mg} / 1$ v. 98 (SEM 4) $\mathrm{mg} / 1$ for a $750 \mathrm{~g}$ intake, $P<0 \cdot 05$ ). The absolute portal blood concentrations were higher (not significant) after the $750 \mathrm{~g}$ meal than after the $500 \mathrm{~g}$ meal. After ingestion of the $500 \mathrm{~g}$ meal, the amino- $\mathrm{N}$ level reached a maximum within $60 \mathrm{~min}$, returning within $8 \mathrm{~h}$ to a level slightly exceeding (not significant) the initial value in the portal vein $\left(C_{p}, 104 \%\right)$ and carotid artery $\left(C_{a}, 101 \%\right)$. After ingestion of the $750 \mathrm{~g}$ meal the maximum was reached earlier $(50 \mathrm{~min})$ and was followed by a second peak of the same magnitude after $150 \mathrm{~min}$; the amino- $\mathrm{N}$ level progressively decreased until the 8th hour after the meal, but the final concentrations exceeded the initial ones $\left(C_{p} 118 \%, P<0.05, C_{a} 109 \%\right.$, not significant). The maximum $C_{p}-C_{a}$ value after ingestion of the $500 \mathrm{~g}$ meal ( $22 \%$ of IC) was smaller (not significant) than after that of the $750 \mathrm{~g}$ meal $(25 \%$ of IC); these differences persisted at a higher level (not significant) after ingestion of the $750 \mathrm{~g}$ meal than after that of the $500 \mathrm{~g}$ meal $(8.6 \mathrm{and}$ 


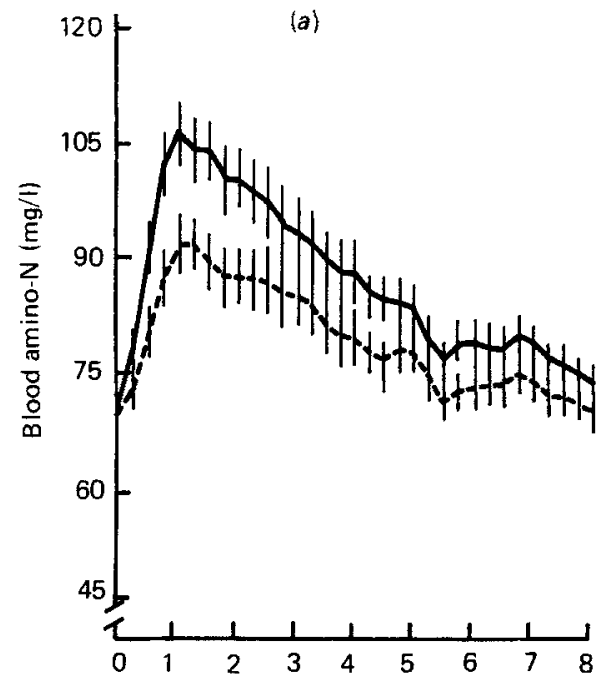

Time-interval after experimental meal (h)

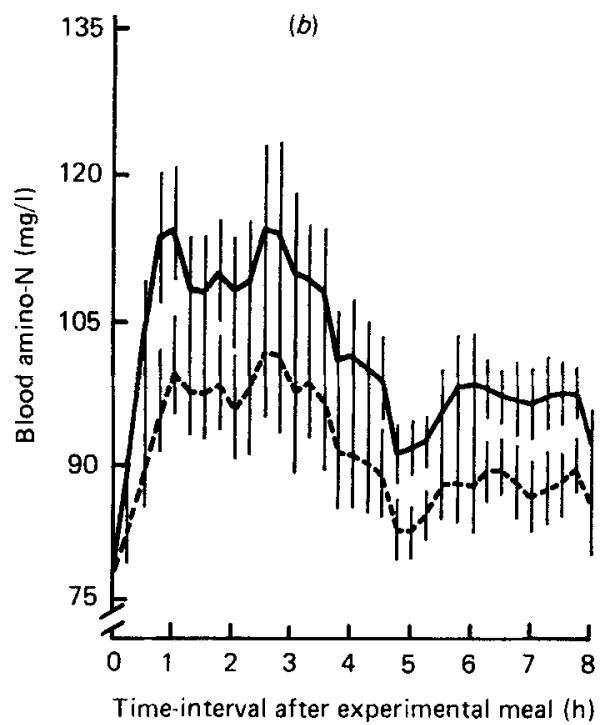

Time-interval after experimental meal (h)

Fig. 1. Variations in blood concentrations of amino-nitrogen (mg/1) in the portal vein (--) and carotid artery (--) during the $8 \mathrm{~h}$ period after ingestion of a meal (fish-protein-containing semi-synthetic diet; for details, see Table 1). (a) Intake $500 \mathrm{~g}$ fresh matter $(120 \mathrm{~g}$ crude protein $(\mathrm{N} \times 6.25 ; \mathrm{CP}) / \mathrm{kg})$, no. of experimental meals $(n) 12 ;(b)$ intake $750 \mathrm{~g}$ fresh matter $(120 \mathrm{~g} \mathrm{CP} / \mathrm{kg}), n 6$. Values are means with vertical bars representing the standard error of the mean.
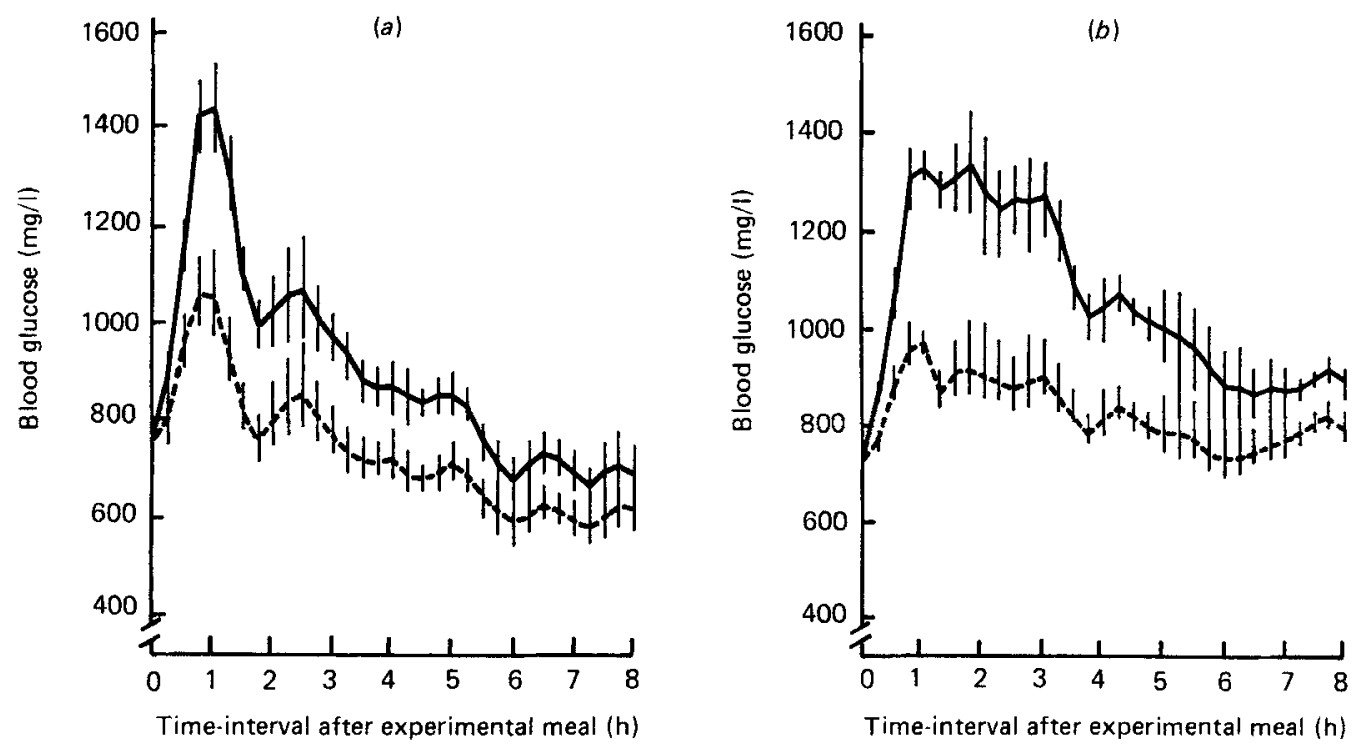

Fig. 2. Variations in blood concentrations of glucose $(\mathrm{mg} / \mathrm{l})$ in the portal vein $(-)$ and carotid artery (-) during the $8 \mathrm{~h}$ period after ingestion of a meal (fish-protein-containing semi-synthetic diet; for details, see Table 1). (a) Intake $500 \mathrm{~g}$ fresh matter $(120 \mathrm{~g}$ crude protein (nitrogen $\times 6.25 ; \mathrm{CP}) / \mathrm{kg}, 289 \mathrm{~g}$ carbohydrate, no. of experimental meals $(n) 10 ;(b)$ intake $750 \mathrm{~g}$ fresh matter $(120 \mathrm{~g} \mathrm{CP} / \mathrm{kg}), 386 \mathrm{~g}$ carbohydrate, $n 5$. Values are means with vertical bars representing the standard error of the mean. 


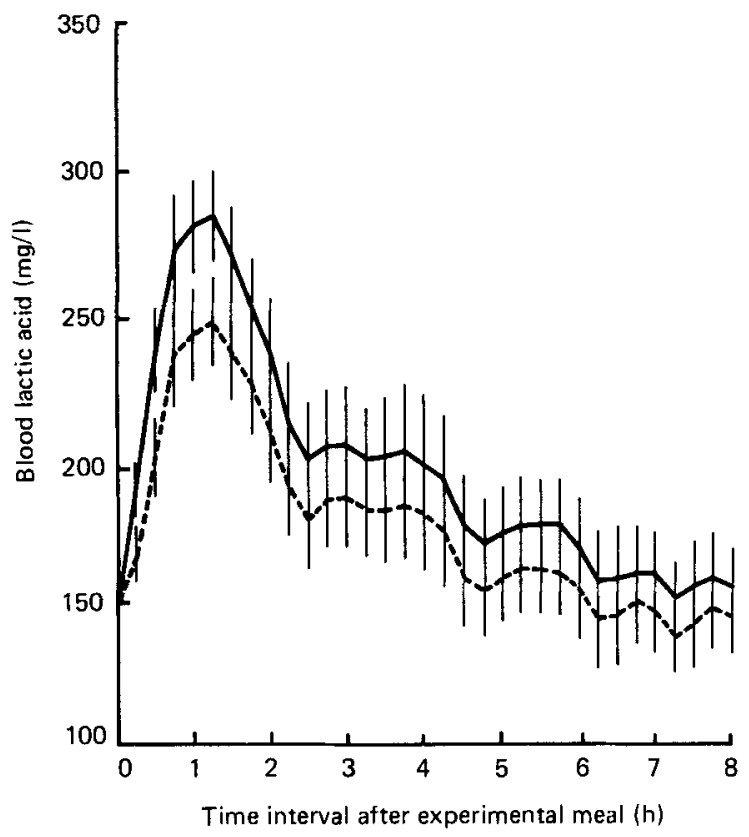

Fig. 3. Variations in blood concentrations of lactic acid $(\mathrm{mg} / \mathrm{l})$ in the portal vein $(-)$ and carotid artery (--) during the $8 \mathrm{~h}$ period after ingestion of a meal (fish-protein-containing semi-synthetic diet; for details, see Table 1). No. of experimental meals 18 (four for 80 g crude protein (nitrogen $\times 6.25 ; \mathrm{CP}$ )/ $\mathrm{kg}$, one for $120 \mathrm{~g} \mathrm{CP} / \mathrm{kg}$, six for $160 \mathrm{~g} \mathrm{CP} / \mathrm{kg}$, seven for $240 \mathrm{~g} \mathrm{CP} / \mathrm{kg}$ ), mean intake (g) 633.6 (SEM 60.9) fresh matter, 106.4 (SEM 11.9) CP, 300.0 (SEM 32.6) carbohydrate. Values are means with vertical bars representing the standard error of the mean.

$5.8 \%$ respectively of IC $8 \mathrm{~h}$ after the meal, not significant). As regards the other levels of feeding, there were not enough values for each level of intake of the same CP diet for the calculation of blood concentration means.

Glycaemia. The reported concentrations concern only the diet containing $120 \mathrm{~g} \mathrm{CP} / \mathrm{kg}$ fed in amounts of $500 \mathrm{~g}$ to ten animals and $750 \mathrm{~g}$ to five animals. After $18 \mathrm{~h}$ of fasting, glycaemia ( $n$ 15) was similar in portal $(745$ (SEM 27) $\mathrm{mg} / 1$ ) and arterial (743 (SEM 25) $\mathrm{mg} / \mathrm{l}$ ) blood. It rapidly increased after the meal and reached a higher maximum in the portal than in the arterial blood (1456 (SEM 96) v. 1072 (SEM 81) $\mathrm{mg} / \mathrm{l}$ after ingestion of $500 \mathrm{~g}$, $P<0.01$; 1336 (SEM 56) v. 978 (SEM 32) $\mathrm{mg} / \mathrm{l}$ after ingestion of $750 \mathrm{~g}, P<0.001$ ), the percentage increase over IC being almost the same for the 500 and $750 \mathrm{~g}$ meals $\left(C_{p} 191 \%\right.$, $C_{a} 142 \% v .188$ and $136 \%$ respectively). This maximum, reached 50 min after the meal, was followed by a rapid decrease in glycaemia after the $500 \mathrm{~g}$ meal and by its maintenance at a rather high level for about $5 \mathrm{~h}$ after ingestion of the $750 \mathrm{~g}$ meal. The final concentrations after $8 \mathrm{~h}$ were lower than the initial ones after ingestion of the $500 \mathrm{~g}$ meal $\left(C_{p} 89 \%\right.$, not significant; $\left.C_{a} 80 \%, P<0.05\right)$ and higher than IC after ingestion of the $750 \mathrm{~g}$ meal $\left(C_{p} 123 \%, P<0.05 ; C_{\mathrm{a}} 110 \%\right.$, not significant $) . C_{p}-C_{a}$ values were at their maximum for the two levels of intake (384 (SEM 31) mg/l for $500 \mathrm{~g} v .358$ (SEM 83) $\mathrm{mg} / \mathrm{l}$ for $750 \mathrm{~g}$ ), but they persisted at a higher level and for longer with the $750 \mathrm{~g}$ meal than with the $500 \mathrm{~g}$ meal; small non-significant differences persisted $8 \mathrm{~h}$ after ingestion of the 500 and $750 \mathrm{~g}$ meals ( 72 (SEM 30 ) $\mathrm{mg} / 1$, i.e. $9 \cdot 8 \%$ of IC and 88 (SEM 30 ) $\mathrm{mg} / 1$, i.e. $12 \cdot 3 \%$ of IC respectively).

Lactacidaemia. This was only measured after feeding of eighteen meals to seven animals and it was not possible to detect differences with time according to the level of intake. The 


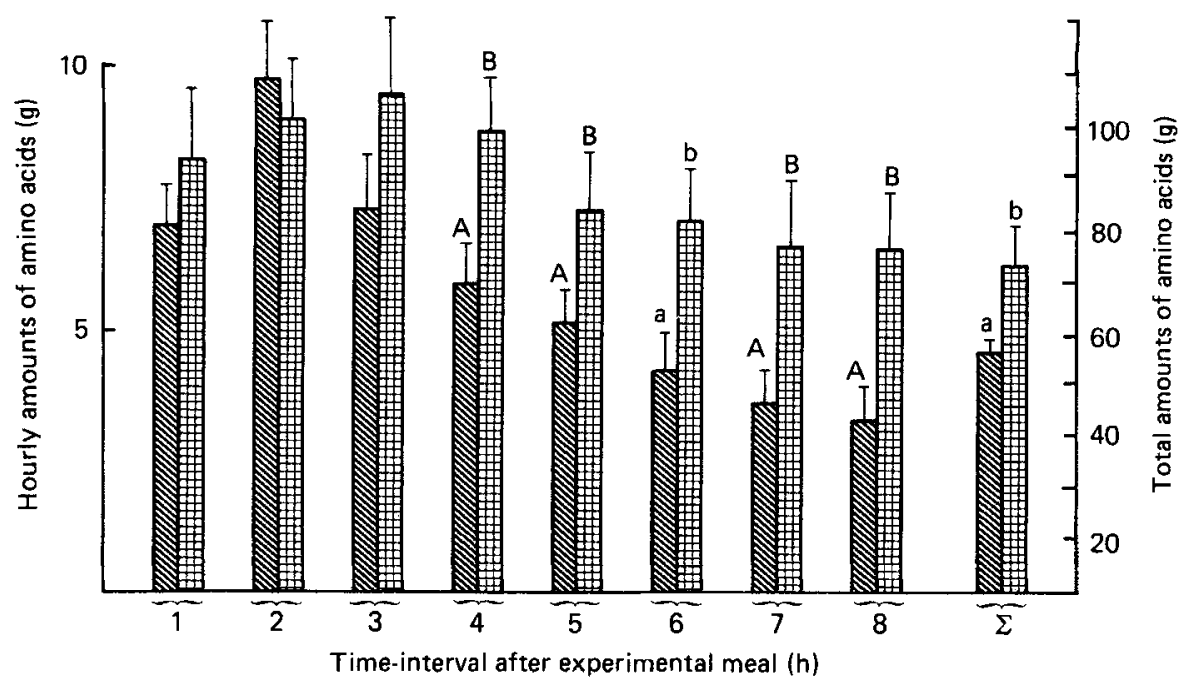

Fig. 4. Amino acid (nitrogen $\times 6.25$ ) amounts (g) appearing in the portal blood at various time-intervals after ingestion of a meal (fish-protein-containing semi-synthetic diet; for details, see Table 1). Intake: (\$), $500 \mathrm{~g}$ fresh matter $(120 \mathrm{~g}$ crude protein $(\mathrm{N} \times 6.25 ; \mathrm{CP}) / \mathrm{kg}$, no. of experimental meals $(n) 12 ;($ 曲), $750 \mathrm{~g}$ fresh matter $(120 \mathrm{~g} \mathrm{CP} / \mathrm{kg}), n 6$. Values are means with vertical bars representing the standard error of the mean. For each hour after the meal, values with different letters were significantly different (A, B $P<0.05 ;$ a, b $P<0.01$ ).

Table 2. Relations between amounts $(\mathrm{Y} ; g)$ of amino-nitrogen absorbed and amounts $(\mathrm{X} ; g)$ of $N$ ingested ( $\mathrm{n} 44 \dagger, d f 42$ ); changes with time-interval after the meal (semi-synthetic diet containing different levels of fish protein $) \ddagger$

\begin{tabular}{|c|c|c|c|c|c|c|}
\hline $\begin{array}{l}\text { Time-interval } \\
\text { after the meal } \\
\text { (h) }\end{array}$ & $Y=$ & $r$ & $X$ & $Y$ & $\begin{array}{c}\text { Statistical } \\
\text { significance }\end{array}$ & $S_{b}$ \\
\hline 2 & $\begin{array}{l}0.069 X+1 \cdot 726 \\
0.800 X^{0.451}\end{array}$ & $\begin{array}{l}0.431 \\
0.533\end{array}$ & $\begin{array}{r}13 \cdot 40 \\
2 \cdot 49\end{array}$ & $\begin{array}{l}2.65 \\
0.90\end{array}$ & $\begin{array}{l}* * \\
* *\end{array}$ & 0.0101 \\
\hline 4 & $\begin{array}{l}0.177 X+2.695 \\
1 \cdot 134 X^{0.575}\end{array}$ & $\begin{array}{l}0.625 \\
0.728\end{array}$ & $\begin{array}{r}13 \cdot 40 \\
2 \cdot 49\end{array}$ & $\begin{array}{l}5.06 \\
1.56\end{array}$ & $\begin{array}{l}* * \\
* *\end{array}$ & 0.0156 \\
\hline 6 & $\begin{array}{l}0.296 X+3.049 \\
1.279 X^{0.658}\end{array}$ & $\begin{array}{l}0.761 \\
0.822\end{array}$ & $\begin{array}{r}13 \cdot 40 \\
2.49\end{array}$ & $\begin{array}{l}7.01 \\
1.88\end{array}$ & ** & 0.0178 \\
\hline 8 & $\begin{array}{l}0.424 X+2.807 \\
1.161 X^{0.768}\end{array}$ & $\begin{array}{l}0.824 \\
0.869\end{array}$ & $\begin{array}{r}13 \cdot 40 \\
2.49\end{array}$ & $\begin{array}{l}8 \cdot 49 \\
2 \cdot 06\end{array}$ & ** & 0.0206 \\
\hline
\end{tabular}

$S_{b}$, standard error of regression coefficient.

** $P<0.01$.

$\uparrow$ No. of experimental meals (twenty animals).

$\ddagger$ No. of meals for each level of crude progein (nitrogen $\times 6.25$ ): seven for $80 \mathrm{~g} / \mathrm{kg}$, twenty-two for $120 \mathrm{~g} / \mathrm{kg}$, six for $160 \mathrm{~g} / \mathrm{kg}$, nine for $240 \mathrm{~g} / \mathrm{kg}$; for amounts ingested, see Fig. 5 .

mean post-prandial variation is shown in Fig. 3. The portal and arterial blood levels of lactic acid, which were similar at time 0 (150 (SEM 11) mg/l and 149 (SEM 11) $\mathrm{mg} / 1$ respectively), increased very rapidly and within $60-75 \mathrm{~min}$ reached a higher (nonsignificant) maximum in the portal than in the arterial blood (285 (SEM 15) mg/l, i.e. $190 \%$ of IC and 250 (SEM 15 ) $\mathrm{mg} / \mathrm{l}$, i.e. $168 \%$ of IC respectively); then it decreased very rapidly (203 (SEM 19) $\mathrm{mg} / \mathrm{l}$ in the portal blood after $195 \mathrm{~min}$ ) and the initial value was reached after 


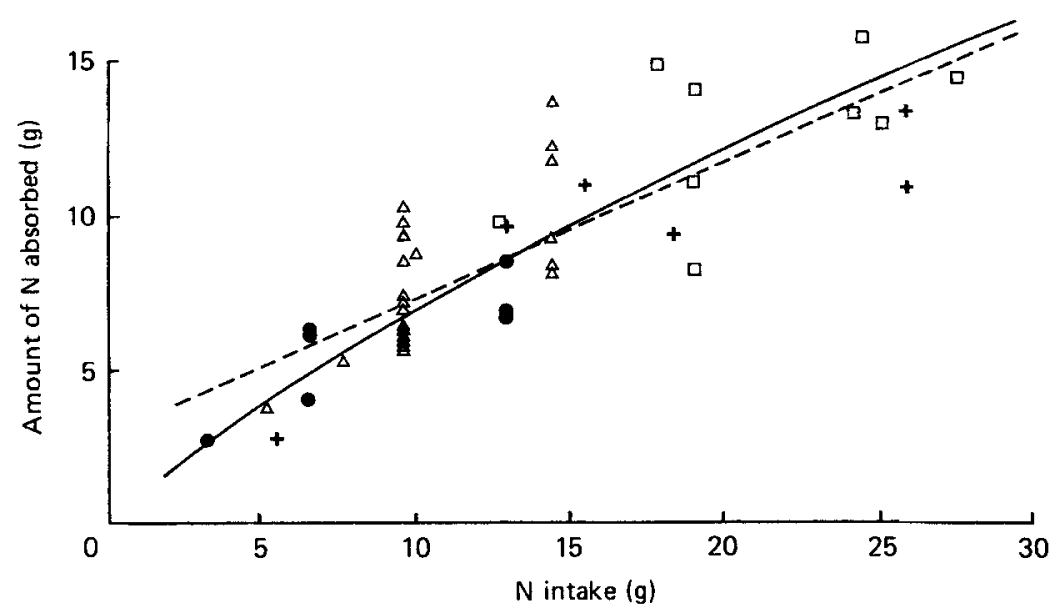

Fig. 5. Relations between the amounts of amino-nitrogen $(Y ; \mathrm{g})$ absorbed within $8 \mathrm{~h}$ after ingestion of a meal and the amount of fish-meal-N ingested $(X ; \mathrm{g})$. N concentration in the $\operatorname{diet}(\mathrm{g} / \mathrm{kg}):(\odot), 12 \cdot 8 ;(\triangle)$, $19 \cdot 2 ;(+), 25 \cdot 6 ;(\square), 38 \cdot 4$. No. of experimental meals 44 . $Y=0.424 X \times 2 \cdot 81, r 0.82, P<0.01$, standard error of regression coefficient $\left(S_{b}\right) 0.0206$.

Table 3. Amounts ${ }^{*}(\mathrm{~g})$ of amino acids and glucose appearing in the portal vein at different time-intervals after a meal (semi-synthetic diet containing different levels of fish protein)

Values in parentheses are coefficients of appearance in the portal blood: amount appeared (g)/amount ingested $(\mathrm{g})$ )

\begin{tabular}{|c|c|c|c|c|c|}
\hline \multirow{2}{*}{$\begin{array}{c}\text { Absorbed } \\
\text { nutrients }\end{array}$} & \multirow{2}{*}{$\begin{array}{l}\text { Intake } \\
(\mathrm{g})\end{array}$} & \multicolumn{4}{|c|}{ Time-interval after the meal (h) } \\
\hline & & 2 & 4 & 6 & 8 \\
\hline \multirow[t]{3}{*}{$\begin{array}{l}\text { Amino acids } \\
(\text { nitrogen } \times 6.25)\end{array}$} & $\begin{array}{l}\text { Protein } \\
(\mathrm{N} \times 6.25)\end{array}$ & & & & \\
\hline & 50 & $14 \cdot 2(0 \cdot 28)$ & $25.7(0.51)$ & $33.9(0.68)$ & $38.7(0.78)$ \\
\hline & 100 & $17.7(0 \cdot 18)$ & $34.5(0 \cdot 34)$ & $48.7(0.49)$ & $59 \cdot 9(0.60)$ \\
\hline \multirow[t]{2}{*}{ Glucose } & Carbohydrate & & & & \\
\hline & $\begin{array}{l}200 \\
400\end{array}$ & $\begin{array}{l}48.6(0.24) \\
71.8(0 \cdot 18)\end{array}$ & $\begin{array}{r}77.9(0.39) \\
128.7(0.33)\end{array}$ & $\begin{array}{r}96.1(0.48) \\
169.1(0.42)\end{array}$ & $\begin{array}{l}107.6(0.54) \\
193.8(0.48)\end{array}$ \\
\hline
\end{tabular}

* Calculated from linear equations (Tables 2 and 4).

$8 \mathrm{~h}$. The $C_{p}-C_{a}$ value reached a maximum within $75 \mathrm{~min}(35 \cdot 5$ (SEM $2 \cdot 2) \mathrm{mg} / \mathrm{l}$, i.e. $24 \%$ of IC); thereafter it decreased progressively to a low level $8 \mathrm{~h}$ after the meal $(10.5$ (SEM 3.1$) \mathrm{mg} / \mathrm{l}$, i.e. $7 \%$ of IC).

\section{Variation in the amounts of nutrients appearing in the portal vein during the post-prandial period}

Amino- $N$. Amounts of amino acids appearing in the portal vein after ingestion of the 500 and $750 \mathrm{~g}$ meals containing $120 \mathrm{~g} \mathrm{CP} / \mathrm{kg}$ are given on an hourly-interval basis in Fig. 4 . The amounts of absorbed amino acids $(\mathrm{N} \times 6.25)$ varied with time and with the level of intake. For the two levels considered together, these amounts represented $7.4 \mathrm{~g}$ during the 1 st hour and tended to increase (not significantly) for $2 \mathrm{~h}(500 \mathrm{~g}$ meal) or $3 \mathrm{~h}(750 \mathrm{~g}$ meal). Thereafter they progressively decreased until $8 \mathrm{~h}$ after ingestion of the $500 \mathrm{~g}$ meal, while they remained 


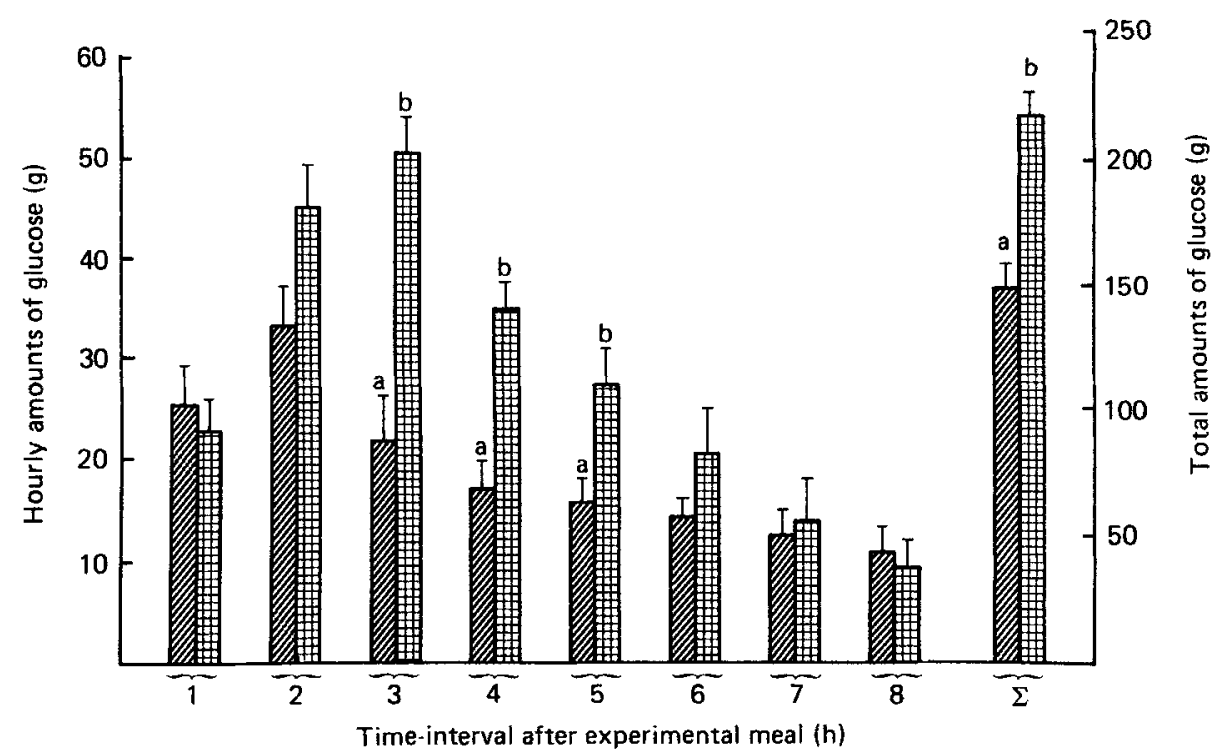

Fig. 6. Amounts of glucose (g) appearing in the portal vein at various time intervals after ingestion of a meal (fish-protein-containing semi-synthetic diet; for details, see Table 1). Intake: (圈), $500 \mathrm{~g}$ fresh matter $(120 \mathrm{~g}$ crude protein (nitrogen $\times 6.25 ; \mathrm{CP}) / \mathrm{kg}, 289 \mathrm{~g}$ carbohydrate, no. of experimental meals $(n)$ $10 ;($ 目), $750 \mathrm{~g}$ fresh matter $(120 \mathrm{~g} \mathrm{CP}) / \mathrm{kg}, 386 \mathrm{~g}$ carbohydrate, $n 5$. Values are means with vertical bars representing the standard error of the mean. For each hour after the meal, values with different letters are significantly different $(\mathrm{a}, \mathrm{b} P<0.01)$.

rather high until $6 \mathrm{~h}$ after ingestion of the $750 \mathrm{~g}$ meal followed by a less-marked decrease than that after the $500 \mathrm{~g}$ meal.

The amounts of amino acids $(\mathrm{N} \times 6.25)$ appearing per hour in the portal blood were significantly different for the two levels of intake $3 \mathrm{~h}$ after the meal and so the cumulative amounts $4-8 \mathrm{~h}$ after feeding were larger after the $750 \mathrm{~g}$ meal than after the $500 \mathrm{~g}$ meal. The coefficients of absorption in the portal vein were 0.76 and $0.69,8 \mathrm{~h}$ after the 500 and $750 \mathrm{~g}$ meals respectively.

Relations between the amounts of amino- $\mathrm{N}$ appearing in the portal blood at various times after the meal and the amounts of $\mathbf{N}$ ingested (Table 2, Fig. 5) were always highly significant $(P<0.01)$ and became closer with increasing time after the meal. Curvilinear regressions described these relations better than the linear regressions but over the $8 \mathrm{~h}$ period there was little difference. The relations were not modified when, instead of the fortyfour meals, only the first meals given to the twenty animals were taken into account (for $8 \mathrm{~h}: Y=0.420 X+2 \cdot 303, r 0.83, n 20$ ). From these relations it may be deduced that, during the $8 \mathrm{~h}$ recording period, the total amounts of absorbed amino acids increased with the amounts ingested while the absorption efficiency decreased (Table 3). These differences occurred very soon after the meal but became more marked with increasing time-interval after the meal.

Glucose. Amounts of absorbed glucose varied with the time-interval after the meal and with the level of intake. For each hourly period (Fig. 6) they increased between 1 and $2 \mathrm{~h}$ after the meal and thereafter they slowly decreased after ingestion of the $500 \mathrm{~g}$ meal while they remained rather high during the first $6 \mathrm{~h}$ after ingestion of the $750 \mathrm{~g}$ meal. The amounts absorbed between 3 and $5 \mathrm{~h}$ after the $750 \mathrm{~g}$ meal were significantly larger than with the $500 \mathrm{~g}$ meal and the cumulative amounts absorbed were significantly higher from 
Table 4. Relations between amounts of absorbed glucose $(\mathrm{Y} ; g)$ and intake of reducing sugars $(\mathrm{X} ; \mathrm{g})(\mathrm{n} 41 \dagger$, df 42$)$; changes with time-interval after the meal (semi-synthetic diet containing different levels of fish protein) $\ddagger$

\begin{tabular}{|c|c|c|c|c|c|c|}
\hline $\begin{array}{l}\text { Time-interval } \\
\text { after the } \\
\text { meal (h) }\end{array}$ & $Y=$ & $r$ & $X$ & $Y$ & $\begin{array}{l}\text { Statistical } \\
\text { significance }\end{array}$ & $S_{b}$ \\
\hline 2 & $\begin{array}{l}0.116 X+25.432 \\
0.395 X^{0.875}\end{array}$ & $\begin{array}{l}0.516 \\
0.643\end{array}$ & $\begin{array}{l}291 \cdot 0 \\
5.605\end{array}$ & $\begin{array}{l}59 \cdot 3 \\
3.974\end{array}$ & $\begin{array}{l}* * \\
* *\end{array}$ & 0.011 \\
\hline 4 & $\begin{array}{l}0.254 X+27.061 \\
0.202 X^{1.087}\end{array}$ & $\begin{array}{l}0.675 \\
0.735\end{array}$ & $\begin{array}{l}291 \cdot 0 \\
5.605\end{array}$ & $\begin{array}{l}100 \cdot 9 \\
4.497\end{array}$ & $\begin{array}{l}* * \\
* *\end{array}$ & 0.016 \\
\hline 6 & $\begin{array}{l}0.365 X+23 \cdot 085 \\
0 \cdot 142 X^{1 \cdot 193}\end{array}$ & $\begin{array}{l}0.726 \\
0.759\end{array}$ & $\begin{array}{l}291 \cdot 0 \\
5 \cdot 605\end{array}$ & $\begin{array}{r}129 \cdot 4 \\
4 \cdot 736\end{array}$ & ** & 0.019 \\
\hline 8 & $\begin{array}{l}0.431 X+31.399 \\
0.108 X^{1.264}\end{array}$ & $\begin{array}{l}0 \cdot 750 \\
0.774\end{array}$ & $\begin{array}{l}291 \cdot 0 \\
5.605\end{array}$ & $\begin{array}{r}146 \cdot 8 \\
4 \cdot 855\end{array}$ & ** & 0.021 \\
\hline
\end{tabular}

$S_{b}$, standard deviation of regression coefficient.

** $P<0.01$.

$\dagger$ No. of meals (twenty animals).

$\ddagger$ No. of meals for each level of crude protein (nitrogen $\times 6.25$ ): seven for $80 \mathrm{~g} / \mathrm{kg}$, nineteen for $120 \mathrm{~g} / \mathrm{kg}$, six for $160 \mathrm{~g} / \mathrm{kg}$, nine for $240 \mathrm{~g} / \mathrm{kg}$; for amounts ingested, see Fig. 7 .

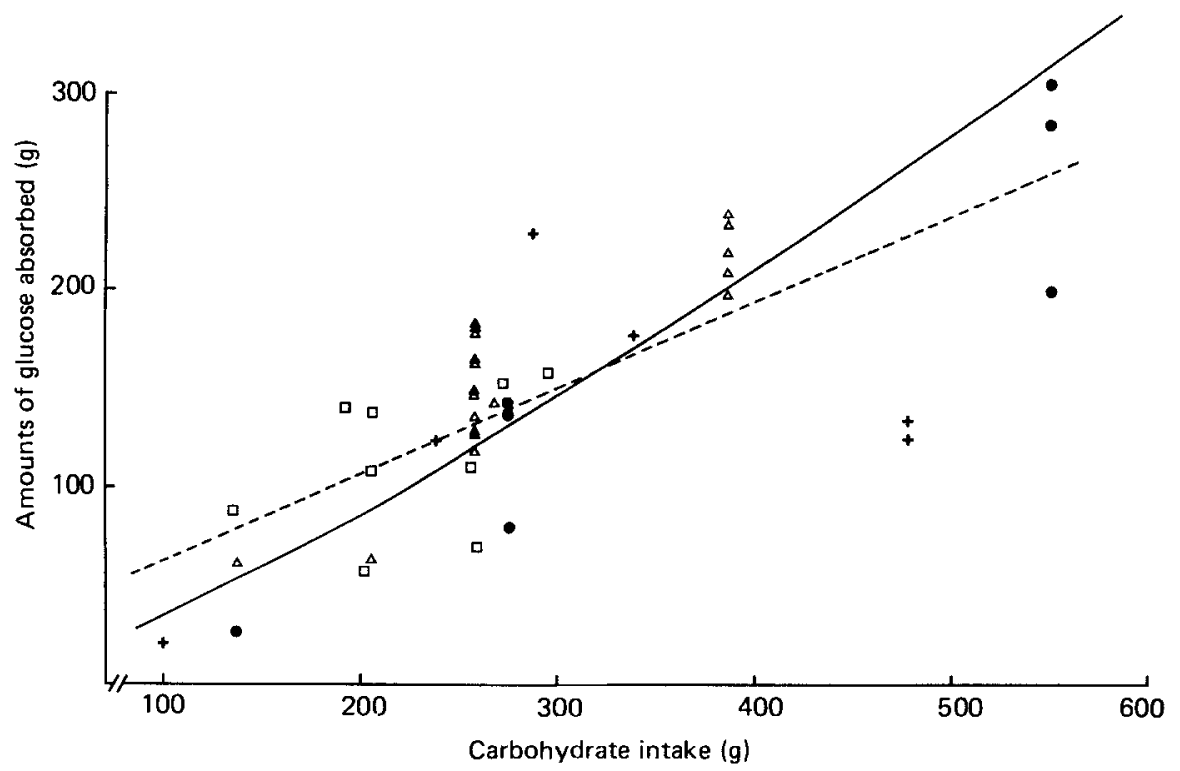

Fig. 7. Relations between the amounts of glucose $(Y ; \mathrm{g})$ absorbed within $8 \mathrm{~h}$ after ingestion of a meal and the amount $(X ; g)$ of carbohydrate ingested (fish-protein-containing semi-synthetic diet; for details, see Table 1). Crude protein (nitrogen $\times 6.25)$ concentration in the diet $(\mathrm{g} / \mathrm{kg}):(\bigcirc), 80 ;(\triangle), 120 ;(+)$, $160 ;(\square), 240$. No. of experimental meals $41 . Y=0.431 X+21 \cdot 40, r 0.75, P<0.01$, standard error of regression coefficient $\left(S_{b}\right) 0.021$.

4 to $8 \mathrm{~h}$ after the meal. The coefficient of absorption after $8 \mathrm{~h}$ ranged from 0.58 after ingestion of the $500 \mathrm{~g}$ meal (i.e. $259 \mathrm{~g}$ carbohydrates) to 0.57 after ingestion of the $750 \mathrm{~g}$ meal (i.e. $386 \mathrm{~g}$ carbohydrates). Relations between the amount of glucose appearing in the portal blood at various time-intervals after the meal and the amount of carbohydrates ingested (Table 4, Fig. 7) were highly significant $(P<0.01)$ and became closer with increasing time- 
Table 5. Changes in amounts of lactic acid $(g)$ appearing in the portal blood relative to the time-interval after the meal ${ }^{*}$

(Mean values with their standard errors of the mean)

\begin{tabular}{lcccccccc}
\hline \hline $\begin{array}{c}\text { Time-interval } \\
\text { after the } \\
\text { meal (h)... }\end{array}$ & 1 & 2 & 3 & 4 & 5 & 6 & 7 & 8 \\
\hline Amounts & & & & & & & & \\
$\quad$ Mean & 3.18 & 3.33 & 2.53 & 2.42 & 2.21 & 1.85 & 1.50 & 1.57 \\
$\quad$ SEM & 0.29 & 0.22 & 0.25 & 0.30 & 0.34 & 0.30 & 0.30 & 0.30 \\
Cumulative amounts & & & & & & & & \\
$\quad$ Mean & & 6.52 & & 11.39 & & 15.49 & 18.46 \\
SEM & 0.45 & & 0.81 & & 1.30 & & 1.74 \\
\hline \hline
\end{tabular}

* Values from eighteen experimental meals (four for 80 crude protein (nitrogen $\times 6.25 ; \mathrm{CP}$ ) $\mathrm{g} / \mathrm{kg}$, one for $120 \mathrm{CP} \mathrm{g} / \mathrm{kg}$, six for $160 \mathrm{CP} \mathrm{g} / \mathrm{kg}$, seven for $240 \mathrm{CP} \mathrm{g} / \mathrm{kg}$ ); mean intake (g) 633.6 (SEM 60.9) fresh matter, 106.4 (SEM 11.9) CP, 300 (SEM 32.6) g carbohydrate.

interval after the meal. The curvilinear regression described these relations more closely than the linear one, particularly for the first $2 \mathrm{~h}$ period. From these relations, it may be deduced that the amounts of absorbed glucose increased with the amounts of carbohydrates ingested while the absorption coefficient slightly decreased (Table 3 ).

The percentage of glucose in the absorbed reducing sugars was 78.0 (SEM 0.03) after meals ( $n$ 18) for which the two measurements were made simultaneously.

Lactic acid. The amounts of lactic acid absorbed did not depend on the amount of food eaten. They were higher immediately after the meal (Table 5) than $8 \mathrm{~h}$ later, when they represented only half the value at $1 \mathrm{~h}$ after the meal; the variability from one meal to another was very large.

\section{DISCUSSION}

The limitations of the methods used to quantify the absorption kinetics have been discussed elsewhere (Rérat et al. 1980, $1984 a, b$ ), but it should be pointed out again that they do not account for total absorption of nutrients as they do not take into account metabolism of nutrients in the gastrointestinal wall.

Determination of amino- $N$ by the TNBS method is not as satisfactory as that by chromatography. It refers to a standard solution containing only one amino acid or, as in the present experiment, an amino acid mixture. It is clear that according to the composition of free amino acids in the blood, the calculation of their total weight from the amino- $\mathrm{N}$ content may be biased but this may not lead to a big error. In considering $C_{p}-C_{a}$, this bias was shown to be small in comparison with chromatographic values (Rérat $e t$ al. 1988). The weight of absorbed free amino acids may be arbitrarily calculated by means of the coefficient 6.25, generally used to calculate dietary protein content from dietary $N$. This system allows comparison of absorbed and ingested amounts, even though the absorbed $\mathbf{N}$ does not fully account for the mixture of amino acids appearing in the blood.

It should also be pointed out that a chemical assessment of reducing sugars involves substances other than carbohydrates. As these substances (such as urea) are liable to be secreted or absorbed in the digestive tract, or both, in variable amounts, the 'reducing sugars' can only supply an approximate estimate of the net absorption of sugars. Therefore, specific measurements of glucose were also made.

Because of experimental difficulties (see p. 93) the actual experimental scheme was 
imbalanced and because of the number of treatments (CP level $\times$ diet intake) it was not possible to apply a classical analysis of variance. Using each of the forty-four experimental meals as an individual value meant that within-animal and between-animal variation were not distinguished. To consider only between-animal variation was to use only one set of values per animal, i.e. the first experimental meal for each of the twenty animals. Using this set of values resulted in almost identical regressions to those derived from the full set of forty-four. Between-animal variation may be estimated from the mean values of the same meal given to different animals (Figs. 4 and 6$)$ : for cumulative values $(8 \mathrm{~h}$ ), the coefficient of variation ranged from 0.06 to 0.09 for amino- $\mathrm{N}$ and from 0.035 to 0.05 for glucose.

The shape of the glycaemia curves established in the present experiment for a meal of $750 \mathrm{~g}$ (i.e about $386 \mathrm{~g}$ carbohydrates) was identical to that measured previously (Rérat $e t$ al. $1984 a$ ) for a similar level of intake ( $400 \mathrm{~g}$ carbohydrate). This was the case both for the period of time required before the maximum was reached and for its level above IC. This was also true for the maintenance of the concentration at the 8th post-prandial hour at a slightly higher level than IC, as well as for the magnitude of the $C_{p}-C_{a}$ when the maximum was reached and thereafter. Maintenance of $C_{p}-C_{a}$ levels $8 \mathrm{~h}$ after the meal accounted for the incomplete digestion of starch, except after small meals; this confirms previous results (Rérat et al. 1984 b). It should be emphasized that the hepatic uptake of glucose was not large enough during the first post-prandial hours to maintain peripheral glycaemia constant (Rérat et al. 1984 a).

Cumulative amounts of glucose appearing in the portal vein increased with increasing time-interval after the meal and with the amount of carbohydrate eaten. Both linear and curvilinear relations were highly significant. But, even if over short time-periods $(2 \mathrm{~h})$ curvilinear functions provided higher correlations than linear ones, over longer periods the curvilinear relations did not describe the data significantly better than the linear ones (Table 4).

Amounts of glucose appearing in the portal vein during the post-prandial period of $8 \mathrm{~h}$ calculated from the regression equations of absorbed glucose relative to ingested carbohydrates for a mean level of intake of $291 \mathrm{~g}$ (corresponding to all the meals) were very similar to those calculated from the regression equation $(Y=0.48 X+41)$ describing the relations between absorbed reducing sugars $(Y)$ and ingested starch $(X)$ (Rérat et al. $1984 b$ ) involving the correction factor 0.85 used to convert absorbed reducing sugars to glucose. The efficiency of absorption calculated in this way was not very high $(0.504)$ because of the large uptake of glucose by the gut wall during transport (Rérat et al. 1984b).

Variations in the portal and arterial levels of amino- $\mathrm{N}$ and in the difference between them accounted for an early and prolonged appearance of amino acids in the body, which is in keeping with findings concerning gastric emptying and passage in the small intestine obtained with the same feed ingredients (Cuber \& Laplace, 1979). Digestion was not complete $8 \mathrm{~h}$ after the meal as evidenced by the persistence of porto-arterial concentration differences; there was also an incomplete hepatic uptake of amino acids from the portal blood during the first post-prandial hours since the peripheral blood level of amino- $\mathrm{N}$ increased markedly and fleetingly. In fact, the apparent absorption was far from complete since the amounts of amino- $\mathrm{N}$ appearing in the portal vein ranged from 76 to $69 \%$ of intake respectively for meals of 500 and $750 \mathrm{~g}(120 \mathrm{~g} \mathrm{CP} / \mathrm{kg})$. This deficit may be of three origins, i.e. (1) digestion was not complete; (2) some amino acids were retained and metabolized in the gut wall as shown by $24 \mathrm{~h}$ absorption balances (Rérat, 1981); (3) some of the proteins were not broken down, but this was probably true for only $15 \%$ of them in the case of fish meal as the ileal $(24 \mathrm{~h}$ ) digestibility in vivo is about $85 \%$ (Darcy et al. 1982). However, the percentage of amino- $\mathrm{N}$ absorbed was almost identical to that measured $(73 \%)$ for a fish meal of the same composition and offered in similar amounts 
(112 g protein, $800 \mathrm{~g}$ diet) in a previous experiment (Rérat et al. 1985). On the other hand, the balance of amino- $\mathrm{N}$ appearance in the portal vein $8 \mathrm{~h}$ after intake of $100 \mathrm{~g}$ protein was analogous to that measured for wheat proteins and much higher than that for barley proteins (Rérat et al. 1979). Thus, the time-course of absorption of amino acids from fish meal and wheat is apparently similar, but faster than that of barley amino acids. However, this has to be considered together with the possible influence of the nature of starches (natural ones in the case of cereals, purified ones in the case of the present semi-synthetic diet) on the time-course of digestion of proteins (Laplace et al. 1983).

Comparison of the amounts of digestion products appearing in the portal vein after ingestion of 500 and $750 \mathrm{~g}$ meals $(120 \mathrm{~g} \mathrm{CP} / \mathrm{kg})$ showed that the $8 \mathrm{~h}$ absorption coefficient of nitrogenous products $(0.76-0.69)$ was much higher than that of carbohydrate products $(0 \cdot 58-0 \cdot 57)$. In the case of a semi-synthetic diet, this difference in the absorptive process between protein and carbohydrate nutrients may have been caused by a slower gastric emptying of starch, as shown by Cuber \& Laplace (1979), or non-optimal starch hydrolysis conditions in the proximal intestine during the first post-prandial hours. With similar diets a lag was observed between the presence of starch in the proximal intestine and the appearance of glucose in the portal vein (Rérat, 1982). Thus, the differential absorption of amino acids and carbohydrates already described in the case of wheat (Rérat et al. 1979) was also observed with this semi-synthetic diet of fish meal and starch.

Cumulative amounts of amino-N appearing in the portal vein increased with increasing time-interval after the meal and with the amount of protein eaten. Both linear and curvilinear relations were highly significant. But, according to the correlation coefficients, it seemed that, for the range of intakes in the present experiment $(4-30 \mathrm{~g} \mathrm{~N})$, the curvilinear relation described the data significantly better than the linear relation over short timeperiods. This may be explained by the saturation of the digestive capacities of the intestine after the largest intakes during the first hours. Thus, with increasing intake, the absorption efficiency was much more reduced over short than over long periods. For the longest period, the linear relation became closer to the curvilinear relation.

Amounts of lactic acid appearing during the post-prandial period were slightly lower than those previously recorded (Rérat et al. 1984b). The quantities of starch ingested in the present experiment were generally lower than in the former one $(311 v .825 \mathrm{~g})$ which might explain the lower production of lactic acid.

It may be concluded that in conscious pigs the ingestion of semi-synthetic diets in variable amounts and including different amounts of fish protein led to increases in portal amino- $\mathrm{N}$ concentration, which increased with protein intake, and portal glucose which increased with starch intake. The arterial amino- $\mathrm{N}$ and glucose concentrations showed less marked and shorter increases indicating that the liver only took up part of the amino acids and glucose from the portal vein during the first hours of digestion. There were close and significant relations between amounts of absorbed amino- $\mathrm{N}$ (or glucose) and amounts of protein (or starch) eaten. These relations became closer with increasing time-interval after the meal. Generally speaking, absorption of glucose was slower than that of amino acids.

The authors are greatly indebted to G. Brachet, F. Cointepas and J. Weber for their technical assistance, J. Gallé for the drawings and to Mrs K. Rérat for the English translation of the manuscript.

\section{REFERENCES}

Agricultural Research Council (1967). The Nutrient Requirements of Farm Livestock, no. 3, Technical Reviews. London: Agricultural Research Council.

Aumaitre, A., Rérat, A., Vaissade, P. \& Vaugelade, P. (1975). Annales de Biologie Animale, Biochimie, Biophysique 15, 547-558. 
Cuber, J. C. \& Laplace, J. P. (1979). Annales de Zootechnie 28, 173-184.

Darcy, B., Laplace, J. P. \& Duée, P. H. (1982). Annales de Zootechnie 31, 279-300.

Henry, Y. \& Rérat, A. (1964). Annales de Biologie Animale. Biochimie, Biophysique 4, 263-271.

Hill, J. B. \& Kessler, G. (1961). Journal of Laboratory and Clinical Medicine 57, 970-990.

Hoffman, S. W. (1937). Journal of Biological Chemistry 120, 511-555.

Laplace, J. P., Pons, O. \& Simon, P. (1983). Annales de Zootechnie 32, 507-524.

Munro, H. N. (1949). Journal of Nutrition 39, 375-391.

Palmer, D. W. \& Peters, R. (1965). Automation in Analytical Chemistry. Technicon Symposium, New York, pp. 324-327. Tassy-Torson, New York: Technicon Instruments Corp.

Rérat, A. (1971). Annales de Biologie Animale, Biochimie, Biophysique 11, 277-279.

Rérat, A. (1981). Bulletin de l'Académie Nationale de Médecine (Paris) 165, 1131-1137.

Rérat, A. (1982). In Digestive Physiology in the Pig. Colloques de l'INRA no. 12, pp. 63-85 [J. P. Laplace, T. Corring and A. Rérat editors]. Paris: Institut National de la Recherche Agronomique.

Rérat, A., Chayvialle, J. A., Kandé, J., Vaissade, P., Vaugelade, P. \& Bourrier, T. (1985). Canadian Journal of Physiology and Pharmacology 63, 1547-1559.

Rérat, A., Jung, J. \& Kandé, J. (1988). British Journal of Nutrition 60, 105-120.

Rérat, A., Vaissade, P. \& Vaugelade, P. (1979). Annales de Biologie Animale, Biochimie, Biophysique 19, $739-747$.

Rérat, A., Vaissade, P. \& Vaugelade, P. (1984a). British Journal of Nutrition 51, 505-515.

Rérat, A., Vaissade, P. \& Vaugelade, P. (1984b). British Journal of Nutrition 51, 517-529.

Rérat, A., Vaugelade, P. \& Villiers, P. (1980). In Current Concepts of Digestion and Absorption in Pigs, Technical Bulletin no. 3, pp. 177-216 [A. G. Low and I. G. Partridge, editors]. Reading/Ayr: National Institute for Research in Dairying/Hannah Research Institute.

Snedecor, G. W. \& Cochran, W. G. (1967). Statistical Methods. Ames, Iowa: Iowa University Press. 